so clearly that almost all his designs, even those of startling novelty, were right the first time or required only correction in detail.

Beyond his refusal to claim credit for what he had done, one found it difficult to get him to admit credit.

His one test for a thing-technically or morally-was whether it was right.

Of all the good airship men who have been lost he leaves a gap which will be most difficult to fill.

\title{
Major Percy Bishop, M.B.E., Associate Fellow
}

Percy Bishop was born in 1888 and educated at Kendrick School, Reading, at the Regent Street Polytechnic, and Sheffield University. $\mathrm{He}$ was apprenticed to Clement Talbot, Ltd., and later served with the Sheffield Simplex Company and with D. Napier and Sons, Ltd. He joined the Royal Aircraft Factory in I9I 2 as a designer and afterwards as chief inspector. In I915 he received a commission in the Royal Flying Corps. He was awarded the M.B.E., both civil and military, in I9I9 in recognition of his services. He continued with the Directorate of Aeronautical Inspection and became Chief Inspector, Aircraft.

Major Bishop was an active and keen member of the Society and served on one of its most important committees of Council, the Grading Committee. Fe was elected an Associate Fellow in 1918.

The following is an abstract from the Times of a tribute paid to Major Bishop by Dr. A. P. Thurston, a personal friend of long standing :-

"As Chief Inspector of Aircraft in the Aeronautical Inspection Directorate, Bishop was known and respected by the heads of every works throughout the land producing material or parts used in or in connection with aircraft. $\mathrm{He}$ was a Berkshire man of typical yeoman stock. His chief characteristics were an intense and unfailing kindness, and an understanding of men, coupled with loyalty and highly efficient practical knowledge of automobile and aeronautical engineering. This knowledge was gained in the works of Clement Talbot, the Sheffield Simplex, D. Napier and Sons, and the Royal Aircraft Factory. He possessed also the shrewdest common sense, and it is no secret that his advice was often sought by those in high authority as well as by leading manufacturers.

"His interest in aeronautics began in I9IO, when he attended a course of my lectures at Sheffield University. On the outbreak of war he was placed in charge of the Inspection Department of the Royal Aircraft Factory, at Farnborough, where his ability was soon recognised by the officers of the Military Aeronautics Directorate. During this period he invented various scientific instruments for accurately gauging aeroplane parts, and wrote a paper which has become a classic.

"He was essentially an aeroplane man-that is, he believed in heavier-thanair craft-but, such was his devotion to duty, he took every possible step to hecome acquainted with the construction and operation of airships. He attended as one of the British representatives the Fifth International Conference on Aeronautics at the Hague." 